\title{
Accountability of the security and intelligence services
}

Sean Kippin and the Democratic Audit team assess the ways in which the UK's four main security services are scrutinised, to ensure that they are operating legally and in the public interest. For matters that must be kept secret, 'compromise' forms of scrutiny have now been developed in Parliament. But how effectively or independently do they work?

\section{What does democracy require for the accountability of security and intelligence services?}

Under normal circumstances, elected legislators usually must control all government services and state operations, either directly or indirectly (that is, via ministers), normally through full public and parliamentary accountability.

At the same time, the state must also maintain a national security, intelligence and defence apparatus sufficient to protect citizens from terrorism and other harms, and to secure national defence - and for much of such activities maintaining secrecy is essential.

Institutional arrangements must balance these contradictory requirements, ideally securing a degree of accountability while preserving essential secrecy.

Given limited public accountability, it is of the first importance that legislative, ministerial and judicial controls are sufficient to ensure that the security and intelligence services respect civil liberties and human rights, and operate within the law - for example, with rigorous complaints and investigation processes that engage high levels of public trust.

In the nature of secret intelligence and espionage matters, there are limits on how far legislative scrutiny can operate via the normal parliamentary channels. Every liberal democracy in the world consequently provides some special machinery of control that is designed to manage the incompatibility between maintaining these vital specials services and ensuring public accountability. 


\section{Parliament's Intelligence and Security Committee (ISC)}

This is the main vehicle used in the UK. It is formally a joint committee of the Houses of Parliament. In practice it is Commons-dominated and is the major way in which MPs in the Westminster Parliament (plus a few peers) exercise a degree of control over the UK's intelligence and security services. These consist of:

MI5 (internal security),

SIS or MI6 (overseas intelligence),

GCHQ (electronic and other surveillance),

the Defence Intelligence Staffs (military intelligence), and

the Joint Intelligence Committee (JIC) in the Cabinet Office, which coordinates and sanctions major operations, reporting to the Prime Minister.

The ISC operates in a quite dissimilar way to the Commons select committees. Its members are drawn from both Houses of Parliament (currently seven MPs and two Lords). They are nominated by the Prime Minister in consultation with opposition party leaders, before being approved by Parliament and they are security-vetted. The Committee generally meets in private (although it has held occasional public sessions). It almost always questions security and intelligence witnesses in private, and issues only heavily vetted summary public reports, designed not to reveal any secret information. The chair of the Committee comes from the government party, is appointed by the Prime Minister, and is very influential in settling its workflow and being the public face of its investigations and reports. They (and committee members) have often (but not always) had a background of supervising security agencies as ministers (see Figure 1). Some people on the ISC are also members of the Privy Council, an appointed executive body sometimes used for handling secret issues and briefings. The publication of ISC reports is also 'negotiated' with the government beforehand, in the past quite speedily, but more recently with longer delays, and even preemptive leaking by Whitehall in 2018.

The ISC is a kind of 'compromise' solution of a type that is quite common in liberal democracies. However, a 2014 report of the Commons' Home Affairs Committee identified three shortcomings in this approach across many countries surveyed:

'the potential for political deference [to ministers and the intelligence services top brass]; the over-identification of the [committee] members with the security and intelligence services; and

the danger confidential information provided to the committee might be leaked'.

\section{Recent developments: up to 2015}

The 2010-15 ISC was criticised as a group of elderly 'trusties', all heavily committed to defending intelligence operations from criticism. Their average age was 63 , they were overwhelmingly male, and the ISC chair was Malcolm Rifkind (aged 67 when he finished, a former foreign and defence secretary), who also had extensive business interests in a number of related areas. 
Serious allegations surfaced in the mid-2000s of UK agencies having colluded with the illegal 'rendition' of suspects by the CIA and US agencies; and of SIS agents knowing of and being complicit in the torturing of suspects by US or foreign intelligence services. The UK government made large payments to British citizens imprisoned in Guantanamo Bay and released without any charges (one of whom later died as a jihadist fighter in Syria). Links between UK services and the Gaddafi regime in Libya have also provoked controversy, and damages have been paid for a rendition of one person. The Committee investigated all the claims against the UK services in 2007 (in some fashion, undisclosed) and pronounced that the fears expressed about them were all unfounded. Later a judgelead inquiry was put in place, but that was wound up in 2013.

In 2013, the scale of surveillance work carried out by Western governments was revealed by Edward Snowden, a US security contractor, who released a great mass of documents to the Guardian and Washington Post newspapers. They showed the existence of a series of programmes pertaining to the mining of phone, internet and other personal communication data, and agreements to share said data between governments, without - in most cases - the knowledge or consent of citizen populations. Essentially GCHQ appeared to be running a 'swapsie' information deal with the US National Security Agency, whereby GCHQ bulk-spied on US citizens for its American counterpart (for whom this would be illegal), in exchange for the NSA bulk-spying on British and European citizens (for which GCHQ would normally need a warrant or ministerial clearance). According to the well-placed observer lan Brown the scale and reach of these activities 'appeared to be a surprise to members of Parliament's Intelligence and Security Committee (ISC), let alone the National Security Council, other parliamentarians, and the broader public.' Under Rifkind's lead, the Intelligence and Security Committee rather promptly cleared GCHQ of any wrongdoing at all, which a former chair of the ISC and Conservative Defence Secretary Lord King described as 'unfortunate' and 'pretty quick'.

In February 2015 Rifkind was involved in a press 'sting' operation (along with former Labour Foreign Secretary, Jack Straw), where Daily Telegraph journalists claimed both men offered to trade lobbying influence for advisor fees. Cleared by a limited Commons investigation, both men's public credibility was none the less impaired. In September 2015 Rifkind stood down as ISC chair.

\section{The post-2015 ISC}

The new ISC chair appointed in 2015 was the Conservative MP Dominic Grieve, a former Solicitor General (government law officer), who has been a prominent defender of the European Convention on Human Rights and someone with a strong civil liberties reputation. He has attracted press coverage over recent years for his stances on issues such as enforced removal of UK passports from citizens, the stalled Gibson Inquiry which looked into the treatment of detainees, and the potential implications of repealing the Human Rights Act. Since Grieve's appointment in September 2015, the ISC has produced five special reports. 
One dramatic report was on drone strikes in Syria in which civilians were killed, at least three of whom were British citizens. David Cameron explained in 2015 that the deaths were the first time a UK drone had been used to kill someone in a country with which Britain was not at war. The report was rushed out in April 2017, with substantial redactions that the ISC had no time to challenge before the general election. In it, the Committee expressed frustration that the government had deemed the strikes a military issue and therefore outside the ISC's remit:

'Oversight and scrutiny depend on primary evidence: without sight of the actual documents provided to Ministers we cannot ourselves be sure - nor offer an assurance to Parliament or the public - that we have indeed been given the full facts surrounding the authorisation process for the lethal strike against [one citizen] Reyaad Khan.'

The ISC reports on the Investigatory Powers Act (IPA) was released in 2016, also known as the 'snoopers' charter', which the Conservative government argued was urgently needed. The Committee was sceptical of the need for bulk hacking powers and said that the bill should include privacy protections. The Act was slightly modified to allay these concerns, with a clause inserted to the effect that mass surveillance powers were not to be used if less intrusive means were available. The civil liberties group Liberty continues to call for a judicial review of the wide-reaching bulk surveillance powers available to government departments and the security services under the IPA.

In June 2018, the ISC released new reports on the treatment of detainees and on rendition, one covering the periods 2001-10 and another covering more recent material. They made a considerable stir. A recent summary (by Blakely and Raphael) argued:

'The two ISC reports are hard-hitting. The first, documenting British involvement in torture in the early 'war on terror', makes previous UK governments' denials of involvement completely untenable. Although Jack Straw famously asserted that only conspiracy theorists should believe the UK played any role in rendition or torture, we now know that British intelligence knew about, suggested, planned, agreed to, or paid for others to conduct rendition operations in more than 70 cases. In hundreds of others, UK officials knew that their allies were subjecting prisoners to cruel, inhuman or degrading treatment (CIDT), and yet continued to supply questions to, and receive intelligence from, those who were tortured.

The second report is no less important. It catalogues a series of failures in government policy, as well as in training and guidance provided to UK security services. The implications are serious: there is every possibility British collusion in torture is being, or could be, repeated.'

Despite this recent activism and evidence of greater ISC independence, demands for further reform remain on the agenda. Lord MacDonald, a former Director of Public Prosecutions, has argued that the Committee ought to become a select committee like 
any other, and criticised the 'partial' nature of the reforms enacted by the 2013 Justice and Security Act. He argued that the reforms:

'unwittingly or not, actually weakened democratic oversight of the security and intelligence agencies through the introduction of closed hearings into our civil justice system in national security cases, while simultaneously failing to strengthen the structures of direct parliamentary oversight in any meaningful way.'

And currently only one of nine ISC members is a woman, so greater diversity is clearly needed there.

\section{Strengths, Weaknesses, Opportunities, Threats (SWOT) analysis}

\section{Current strengths}

The ISC follows the pattern of a common, minimum or compromise solution used in several liberal democracies.

It creates some appearance of an independent parliamentary capacity to investigate - one that is separate from ministers.

For the first time, the heads of the security services were questioned in front of the ISC in public, and the Director of MI5 has in addition been interviewed on the Today programme, suggesting a new willingness to engage with the public via the media.

ISC members are able to require the security agencies to produce information pertaining to their activities, a stronger power than is granted to standard select committees which only have the power to 'request' departmental information.

\section{Current weaknesses}

The Committee has a modest staff, no investigatory powers and can only conduct very limited private hearings with the heads of agencies.

The ISC is in principle able to consider any operational matter, but only if it is a matter of significant national interest and does not form part of an ongoing operation. Since security operations often take place over a long period, this is a significant restriction.

Despite the ability to request information from the security services and other governmental bodies engaged in intelligence work, sensitive material is subject to veto at Secretary of State level on grounds that are not limited to national security.

Inherently the Committee is not normally able to publish much of the evidence that it has taken, but can only pronounce its conclusions. 


\section{Current strengths}

Under Dominic Grieve's chairmanship, the ISC has shown a willingness to defend privacy concerns in the face of bulk surveillance. The two 2018 reports on rendition and torture of detainees show a (lagged) movement towards greater openness.

The Committee has also reported on UK drone strikes, although that report was heavily redacted.

\section{Current weaknesses}

The ISC remains to a considerable degree in hoc to the government, with the Prime Minister and Leader of the Opposition nominating ISC members. Additionally, the Prime Minister continues to receive ISC reports ahead of publication, and retains the right to choose the timing of publication, and even to veto the publication of certain elements of the report. (This scrutiny power is probably mostly delegated to the Permanent Secretary who chairs the Cabinet Office's Joint Intelligence Committee.)

The Committee has no legal obligation to investigate and make public the kinds of intelligence service work that may create controversy because of invasions of civil liberties or human rights. Nor does it have any duty to educate or to explain the intricacies of intelligence work to both parliamentarians and members of the public.

The ISC remains a one-off and heavily 'siloed' body with little transfer of knowledge or expertise from a core group of representatives to the wider Parliament.

\section{Future opportunities}

The current ISC chair (Grieve) has a good reputation for taking rights issues seriously, and legal knowledge.

\section{Future threats}

With the growth of violent extremism, and other threats, externally, and the increasing scale of homeland security interventions, the absence of more credible parliamentary safeguards for UK citizens may fuel problems. Similarly, issues around foreign powers potentially intervening in UK elections and referenda have not been speedily addressed by the ISC, unlike in the USA.

The Justice and Security Act (2013) ended the anomalous situation by which the secretariat to a parliamentary committee was provided by Cabinet Office civil servants (itself a government department with intelligence responsibilities). The ISC now has its own, dedicated staff - which may help it to take a more independent attitude over time.
The provisions of the RIPA 2000 (Regulatory and Investigatory Powers Act) are being greatly extended by current legislation giving security services greater powers to hoover up the electronic communications of all citizens without warrants. ISC has no apparent resources for effectively monitoring the use of such powers. 


\section{Future opportunities}

One of the least well-covered and most secretive areas of UK state activity concerns the operations of the large and well-funded UK 'special forces', including the SAS. Here blanket secrecy has been maintained, but the ISC chair (Dominic Grieve) observed in 2017 that: 'in a modern democracy, having areas of state activity that are not subject to scrutiny at all by parliament is not a very good place to be.' Critics argue that either the ISC's remit should be extended from intelligence to also cover special forces operations, or that the Defence Select Committee should have oversight.

\section{Future threats}

If the government deems an issue a military one then it falls outside the ISC's remit. Changing methods of warfare (for example, towards digital weapons and drones) make this an increasingly likely occurrence.
Some observers detect signs of Whitehall mobilising against a more combative ISC - for example, in the pre-emptive leaking of misleading details of the 2018 rendition reports.

Security issues are supposed to be safeguarded in the UK's exit from the European Union, but uncertainty clouds many issues here. It is not clear that the ISC can match the level of vigilance and speedy scrutiny that other commons select committees have demonstrated on the implementation of Brexit. 


\section{Chairs of the Intelligence and Security Committee}

This key role has tended to be given to former ministers, with a preference for those who have served in governmental positions in which security clearance is required. Figure 1 below shows that only Ann Taylor had served in ministerial positions that did not pertain to security matters prior to her appointment.

Figure 1: Chairs of the Joint Intelligence and Security Committee since its creation in 1994

\begin{tabular}{|c|c|c|c|}
\hline Chair & $\begin{array}{l}\text { Time position } \\
\text { held }\end{array}$ & $\begin{array}{l}\text { Former government positions } \\
\text { (prior to JISC) }\end{array}$ & Party \\
\hline Dominic Grieve & $2015-$ & Attorney General* & Conservative \\
\hline $\begin{array}{l}\text { Sir Malcolm } \\
\text { Rifkind }\end{array}$ & 2010-15 & $\begin{array}{l}\text { Foreign Secretary* } \\
\text { Defence Secretary* } \\
\text { Transport Secretary } \\
\text { Scottish Secretary }\end{array}$ & Conservative \\
\hline Kim Howells & $2008-10$ & $\begin{array}{l}\text { Minister for Foreign Affairs* } \\
\text { Higher Education Minister } \\
\text { Transport Minister }\end{array}$ & Labour \\
\hline Margaret Beckett & Jan-Oct 2008 & $\begin{array}{l}\text { Foreign Secretary* } \\
\text { Environment Secretary } \\
\text { Leader of the Commons } \\
\text { President of the Board of Trade }\end{array}$ & Labour \\
\hline Paul Murphy & $2005-8$ & $\begin{array}{l}\text { Welsh Secretary } \\
\text { Northern Ireland Secretary* }\end{array}$ & Labour \\
\hline Ann Taylor & $2001-5$ & $\begin{array}{l}\text { Government Chief Whip } \\
\text { Leader of the Commons }\end{array}$ & Labour \\
\hline Tom King & 1994-2001 & $\begin{array}{l}\text { Defence Secretary* } \\
\text { Northern Ireland Secretary* } \\
\text { Employment Secretary } \\
\text { Transport Secretary }\end{array}$ & Conservative \\
\hline
\end{tabular}

* Position involves supervising security services

\section{Reporting by the Committee}

The Intelligence and Security Committee is now required to release an annual report on 'the discharge of its functions' and 2013 legislation 'enables it to make any other reports as it considers appropriate concerning any aspects of its functions'. This differs from the situation before the 2013 Act was implemented, which required the ISC to make its reports to the Prime Minister alone. However, the Prime Minister still enjoys foresight of reports and can delay their publication or veto the release of certain information.

The committee may also make other reports on issues and topics that it views as important. For example, in November 2014, it produced a report on the murder of an off-duty soldier 
Lee Rigby in a London street by two jihadist terrorists. The range and frequency of reports increased with 'Women in the Intelligence Community' in March 2015, and a follow-up one on diversity and inclusion in 2018. In 2015 it also published 'Privacy and Security: a modern and transparent legal framework'. After Donald Trump claimed that President Barack Obama had asked the UK to wiretap him while he was candidate for the presidency, Dominic Grieve said in a statement that it was 'inconceivable' that GCHQ could have done so.

\section{Political neutrality, transparency and openness}

Before 1994 the UK's official attitude to the security services was not to even acknowledge their existence. A more open approach has also now lead some of the main UK security agencies recently to engage more actively in public debate, partly because they use public appearances to lobby for increased surveillance powers in battling terrorism, cyberattacks and major crime. The Director of MI5 Andrew Parker agreed to be interviewed by the BBC's Today programme in September 2015 - but then did not reveal anything by way of new information. Instead Parker used the interview to justify the passage of the draft Investigatory Powers Act. Robert Harrington, the normally reclusive head of GCHQ, wrote an opinion piece for the Financial Times in which he made the case for a new understanding between the security services, social media companies and the public.

The first ever evidence session at which ISC members publicly questioned the agency heads was held in late 2013. An academic expert on the ISC, Andrew Defty, noted that:

'Some of the questions were clearly designed to allow the agency heads to make prepared statements dispelling popular myths about their work. It is hardly tenable, for example, that [the then-ISC chair] Sir Malcolm Rifkind really believes that GCHQ collects information on "the majority of the public". But his suggestion that they did, allowed the head of GCHQ to refute the notion.'

\section{Conclusions}

The Intelligence and Select Committee remains an imperfect and very limited body for the regulation of the large, powerful, and secretive intelligence services. Despite recent reforms which have seen the body become a committee of Parliament, and with influence over its membership extended to Parliament, it is still a body over which the government and Prime Minister exercise an enormous amount of influence. Choreographed evidence sessions between the committee and the Service heads suggest an over-co-operative, too close relationship. So too does the past willingness of the committee to very promptly exonerate the GCHQ in regard to the Snowden revelations and the charges of data collection and surveillance exceeding the agency's remit - a clearance that occurred while the revelations were still emerging. Although the ICS criticised the lack of privacy safeguards in the Investigatory Powers Bill, it did not secure major changes in the final Act.

Sean Kippin is a PhD candidate and Associate Lecturer at the University of the West of Scotland and a former editor of Democratic Audit. 